\title{
RESIDU PESTISIDA PIRETROID PADA BAWANG MERAH DI DESA SRIGADING KECAMATAN SANDEN KABUPATEN BANTUL
}

\section{PYRETHROID PESTICIDE RESIDUE IN ONION FROM SRIGADING VILLAGE SANDEN DISTRICT BANTUL REGENCY}

\author{
Iin Narwanti ${ }^{1}$, Eko Sugiharto ${ }^{2}$, Chairil Anwar ${ }^{2}$ \\ Fakultas Farmasi Universitas Ahmad Dahlan \\ Jln. Prod. Dr. Supomo Yogyakarta, Telp. (0274) 379418
}

\begin{abstract}
Abstrak
Telah dilakukan penelitian terhadap residu pestisida piretroid pada sampel bawang merah di Desa Srigading, Kecamatan Sanden, Kabupaten Bantul. Penelitian ini bertujuan untuk menganalisis, mengidentifikasi dan mengevaluasi residu pestisida piretroid pada bawang merah. Sampel bawang merah diekstraksi menggunakan alat homogenizer dengan pelarut aseton. Clean-up dilakukan dengan kolom kromatografi menggunakan florisil dan selanjutnya kadar residu pestisida ditentukan dengan kromatografi gas yang dilengkapi dengan detektor tangkapan elektron (Electron Capture Detector/ECD). Hasil penelitian menunjukkan bahwa sampel bawang merah terdeteksi adanya residu pestisida piretroid ( $\alpha$-sipermetrin dan $\lambda$-sihalotrin). Kisaran residu pestisida pada sampel bawang merah untuk $\alpha$-sipermetrin $(98,8-245,6$ ppb) dan $\lambda$-sihalotrin (14,4-120,0 ppb). Terdapat sampel bawang merah yang melebihi Batas Maksimum Residu (BMR).
\end{abstract}

Kata kunci : residu pestisida, piretroid, Batas Maksimum Residu

\footnotetext{
${ }^{2}$ Fakultas MIPA Unversitas Gadjah Mada

Email: iin.narw@gmail.com
} 


\section{Abstract}

Pyrethroid pesticide residue in onion from Srigading Village, Sanden District, Bantul Regency has been investigated. The purpose of this study were to analyze, identificate and evaluate pyrethroid pesticide residues in onion. Onion sample was extracted using homogenizer with acetone solvent. Clean-up was done using chromatography column using florisil and determination of pesticide residue in the samples was carried out by gas chromatography apparatus equipped with electron capture detector (GC-ECD). The result showed that pesticide residues in onion sample in the range level: $\alpha$-cypermethrin (98.8-245.6 ppb) and $\lambda$-cyhalothrin (14.4-120.0 ppb). The following pesticides have been detected in some of samples of onion analysed, but they have been detected above the Maximum Residue Limit (MRL).

Keywords : pesticide residue, pyrethroid, Maximum Residue Limit

\section{PENDAHULUAN}

Bawang merah merupakan salah satu komoditas sayuran yang secara rutin dikonsumsi manusia. Budidaya komoditas unggulan ini, sejak lama telah diusahakan oleh petani secara intensif. Tanaman bawang merah bersifat rentan terhadap hama dan penyakit. Penyakit yang biasa menyerang bawang merah, antara lain: bercak daun (early blight) dan busuk daun (late blight), sedangkan hamanya antara lain ulat penggerek buah, daun dan leher batang, ulat grayak serta kutu daun. Serangan penyakit dan hama pada bawang merah seringkali tidak dapat dihindari, sehingga mengakibatkan produksi bawang merah menurun dan tidak menutup kemungkinan terjadi gagal panen. Usaha yang dilakukan petani sebagai upaya preventif dan pengendalian hama/penyakit dengan menggunakan pestisida.

Menurut sifat kimianya pestisida dibagi menjadi 4 yaitu organoklor, organofosfat, karbamat dan piretroid. Dalam penelitian ini, pestisida yang dikaji merupakan golongan insektisida piretroid.

Piretroid mempunyai sifat sebagai iritan, tidak mudah teradsorbsi ke kulit, tetapi mudah teradsorbsi melalui membran pencernaan dan pernafasan. Toksisitas sistemik piretroid setelah paparan melalui kulit adalah rendah, tetapi dampak paparan jangka pendek piretroid (sipermetrin, deltametrin, esfenvalerat, fenvalerat dan permetrin) ternyata memperlihatkan efek yang terlokalisasi pada kulit. Pada mamalia, piretroid dapat menurunkan produksi estradiol (Chen dkk., 2005), menyebabkan efek estrogenik pada mamalia betina dan antiandrogenik pada mamalia jantan (Kim dkk., 2005). Beberapa piretroid juga terkait dengan sistem endokrin, yaitu dapat mempengaruhi perkembangan sistem reproduksi dan seksual, mengganggu 
sistem kekebalan dan meningkatkan resiko kanker.

Penggunaan pestisida piretroid yang cenderung tinggi dan terusmenerus tanpa memperhatikan kaidah pengendalian hama dapat menimbulkan dampak negatif, yaitu: menurunnya kualitas lingkungan dan menurunnya keanekaragaman hayati. Di samping itu, peningkatan penggunaan pestisida dalam jangka waktu yang panjang menimbulkan permasalahan yang baru, yaitu spesies atau hama yang dikendalikan oleh petani menjadi resisten terhadap pestisida yang digunakan.

Aplikasi pestisida pada sayuran dapat meninggalkan residu pestisida baik di lingkungan maupun sayuran. Residu pestisida di lingkungan maupun sayuran telah banyak dilaporkan oleh beberapa peneliti. Ohsawa dkk. (1985) melaporkan bahwa terdapat residu deltametrin sebesar 0,15 ppm pada wortel dan 0,01 ppm pada seledri. Di Jawa Tengah, pada tanaman wortel terdapat residu permetrin sebesar 0,02 ppm (Laksanawati dkk., 1994). Sentra produksi sayuran di beberapa lokasi di Pulau Jawa (1996-2000) terungkap bahwa di dalam sayuran, tanah dan air irigasi mengandung residu pestisida organoklor, organofosfat dan karbamat, dimana kadar residu pestisida pada sayuran dataran rendah bawang merah (di Brebes) dan sayuran dataran tinggi ada yang mempunyai kadar residu melebihi BMR (Batas Maksimum Residu) (Ardiwinata dkk., 1999; Harsanti dkk., 1999; Jatmiko dkk., 1999).

Dalam penelitian ini dilakukan identifikasi dan penentuan residu pestisida piretroid dari lahan pertanaman bawang merah di Desa Srigading yang merupakan sentra produksi bawang merah dengan rata-rata produksi bawang merah sebesar 91,50-132,24 Kw/Ha. Petani bawang merah cenderung menggunakan pestisida secara tidak terkendali. Frekuensi aplikasi pestisida dilakukan 1-2 kali per minggu, tapi ketika hama atau penyakit menyerang, frekuensi aplikasi pestisida dilakukan sampai 3 kali per minggu atau bahkan setiap hari.

Adanya aplikasi pestisida piretroid oleh petani untuk mengatasi hama maupun penyakit pada bawang merah kemungkinan besar menyebabkan adanya residu pestisida piretroid dalam bawang merah dan lingkungan sekitarnya, oleh karena itu dalam penelitian ini dikaji dampak aplikasi pestisida di lahan pertanian bawang merah.

\section{METODE PENELITIAN}

\section{Bahan}

Bahan yang digunakan dalam penelitian ini, meliputi: aseton (E. Merck), n-heksana (E. Merck), $\mathrm{Na}_{2} \mathrm{SO}_{4}$ anhidrat (E. Merck), florisil, karbon aktif, celite 545-magnesium, kertas saring, akuades, larutan standar pestisida piretroid ( $\alpha$-sipermetrin dan $\lambda$-sihalotrin), sampel bawang merah.
Alat
Alat yang digunakan dalam penelitian ini, meliputi: penggojog mekanik (shaker), kolom florisil, alat-alat gelas, rotary evaporator, alat homogenizer, pompa vakum, penyaring Buchner, penangas air, timbangan analitik, satu set kromatografi gas 
(GC-2014 Shimadzu) yang dilengkapi dengan ECD dan kolom Rtx-1 (panjang kolom $30 \mathrm{~m}$, diameter dalam $0,25 \mathrm{~mm}$ ).

\section{Jalannya Penelitian}

Sampel bawang merah dari lahan pertanian diambil sampel produk bawang merah dengan setiap unit sampel berisi sekitar 0,5-1 $\mathrm{kg}$. Sampel produk bawang merah dimasukkan ke dalam kantong kertas sampul ukuran A4 kemudian diberi label yang memuat keterangan: kode, tanggal pengambilan, dan lokasi (desa, kecamatan, dan kabupaten).

Penyiapan sampel bawang merah dimulai dengan mencincang sampel bawang merah dan mencampur dengan seksama untuk mendapatkan sampel yang homogen sebelum diambil sebagian untuk dianalisis. Sampel produk bawang merah yang masih segar diiris halus dan dihomogenkan. Selanjutnya ditimbang sebanyak 25 gram, lalu dimasukan ke dalam mangkuk homogenizer dan ditambahkan pelarut aseton sebanyak $100 \mathrm{~mL}$, kemudian tutup homogenizer ditekan dan set waktu selama 20 menit dengan kecepatan 100 $\mathrm{rpm}$. Setelah itu, sampel difiltrasi dengan corong Buchner dan pelarut ditampung dalam labu bundar $300 \mathrm{~mL}$.

Hasil filtrasi dievaporasi dengan evaporator, kemudian dilakukan pemurnian/clean-up dengan melewatkannya pada kolom kromatografi yang telah diisi oleh florisil dan sodium sulfat anhidrat dan dielusi dengan pelarut n-heksana sebanyak $50 \mathrm{~mL}$, setelah selesai larutan sampel dievaporasi lagi sampai $\pm 1 \mathrm{~mL}$ kemudian labu dibilas dengan aseton secara bertahap dan hasil bilasannya ditampung dalam tabung uji sampai didapatkan volume $10 \mathrm{~mL}$ dan larutan sampel siap disuntikkan ke kromatografi gas.

Kurva standar dibuat dengan membuat serial larutan standar pestisida. Sebanyak $1 \mu \mathrm{L}$ larutan standar diinjeksikan pada alat kromatografi gas sehingga diperoleh hubungan konsentrasi dengan luas area larutan standar. Dari hubungan tersebut ditentukan persamaan garis, koefisien korelasi dan slopenya dengan program SAS, sedangkan batas deteksi atau Limit of Detection (LOD) ditentukan dengan pengolahan secara matematis kurva larutan standar. Kondisi kromatografi gas untuk analisis residu pestisida adalah: tipe kromatografi gas: GC-2014 Shimadzu; suhu injektor: $230^{\circ} \mathrm{C}$; suhu kolom: $270^{\circ} \mathrm{C}$; jenis kolom: Rtx-1 (panjang kolom $30 \mathrm{~m}$, diameter dalam $0,25 \mathrm{~mm}$ ); fasa gerak: gas $\mathrm{N}_{2}$, laju 22 $\mathrm{mL} /$ menit,tekanan $65 \mathrm{kPa}$ ); fasa diam: crossbond $100 \%$ dimetil polisiloksan: detektor ECD. Selanjutnya dilakukan penyuntikan sebanyak $1 \mu \mathrm{L}$ larutan sampel siap suntik dan larutan standar pestisida ke kromatografi gas hingga diperoleh luas puncak dan waktu retensi.

\section{HASIL DAN PEMBAHASAN}

\section{Analisis Residu Pestisida}

Pada penelitian ini, residu pestisida piretroid $(\alpha$-sipermetrin dan $\lambda$-sihalotrin) dianalisis dengan menggunakan alat kromatografi gas. Preparasi sampel dengan proses ekstraksi, clean-up dan penentuan residu pestisida.

Ekstraksi dilakukan dengan alat homogenizer dipilih karena efisiensinya 
yang lebih baik dibandingkan dengan metode yang lain. Tujuan ekstraksi ini, untuk memisahkan secara kuantitatif analit dari matriks pembawanya (koekstraktan). Dengan adanya koekstraktan ini dapat berpengaruh pada efisiensi ekstraksi dan clean up.

Untuk analisis residu pestisida, florisil merupakan adsorben yang biasa digunakan sebagai kolom clean-up. Florisil merupakan senyawa magnesium silikat, $\mathrm{Mg}_{2} \mathrm{SiO}_{3}$, yang dihasilkan dari presipitasi natrium silikat dengan magnesium sulfat. Proses clean-up dengan kolom florisil ini, ko-ekstraktan yang terdapat pada sampel komoditas pertanian seperti lemak, fosfolipid, pigmen, lilin dan pengotor lainnya dapat dihilangkan. Lee dkk. (1982) melaporkan bahwa florisil ini sangat baik digunakan untuk sampel yang berlemak maupun tak berlemak dan juga memperlihatkan nilai perolehan kembali relatif lebih tinggi bila dibandingkan dengan adsorben lainnya. Menurut Ishii (2003), proses clean-up dengan kolom florisil ini dilakukan untuk memfasilitasi penentuan residu insektisida dengan GC-ECD atau HPLC.

Kondisi sistem kromatografi gas dalam penelitian ini sebagai berikut; temperatur injektor, $250^{\circ} \mathrm{C}$; splitless injection pada volume 1iL dengan auto injector; laju alir gas $\mathrm{N}_{2}, 22 \mathrm{~mL} / \mathrm{menit}$; kolom kapiler; Rtx-1 (30 m x 0,25 mm x 0,25 ìm) dengan fasa diam crossbond 100\% dimetilpolisiloksan; temperatur kolom, $230^{\circ} \mathrm{C} ; \quad \mathrm{ECD}$; temperatur detektor: $250^{\circ} \mathrm{C}$.

Dengan alat kromatografi gas, maka diperoleh hasil berupa kromatogram yang akan digunakan untuk konfirmasi identitas senyawa yang dianalisis. Waktu retensi merupakan waktu yang diperlukan oleh solut untuk bermigrasi. Waktu retensi standar pestisida $\alpha$-sipermetrin dan $\lambda$-sihalotrin disajikan pada Tabel I.

Tabel I. Waktu retensi larutan standar pestisida $\alpha$-sipermetrin dan $\lambda$-sihalotrin

\begin{tabular}{|lc|}
\hline \multicolumn{1}{|c|}{ Senyawa } & Waktu Retensi \\
\hline Piretroid: & \\
$\alpha$-Sipermetrin & 7,099 \\
$\lambda$-Sihalotrin & 11,841 \\
\hline
\end{tabular}

Waktu retensi tiap-tiap komponen spesifik, karena ditentukan oleh karakteristik komponen yang bersangkutan, sehingga puncak kromatogram dapat digunakan sebagai parameter kualitatif. Sedangkan untuk keperluan analisis kuantitatif diambil dari fakta bahwa luas puncak kromatogram suatu komponen akan berbanding dengan kadarnya (Willard dkk., 1988).

\section{Kadar Residu Pestisida Piretroid}

Pestisida piretroid merupakan pestisida yang cukup banyak digunakan untuk mengontrol hama-hama dalam budidaya bawang merah. Frekuensi aplikasi piretroid yang tinggi sangat memungkinkan terdapatnya residu pada produk tanah, air maupun bawang merah. Pestisida piretroid yang dianalisis dalam penelitian ini adalah $\alpha$-sipermetrin dan $\lambda$-sihalotrin.

Dari hasil analisis dengan kromatografi gas, terlihat bahwa sampel bawang merah terdeteksi residu baik $\alpha$-sipermetrin maupun $\lambda$-sihalotrin. 
Tabel II. Kisaran residu pestisida piretroid pada bawang merah

\begin{tabular}{|c|c|}
\hline Senyawa & Kisaran Residu (ppb) \\
\hline$\alpha$-Sipermetrin & $(98,8-245,6)$ \\
\hline$\lambda$-Sihalotrin & $(14,4-120,0)$ \\
\hline
\end{tabular}

Kelarutan $\alpha$-sipermetrin dan $\lambda$-sihalotrin dalam air adalah rendah yaitu masingmasing sebesar 0,004 dan $0,005 \mathrm{mg} / \mathrm{L}$ pada temperatur $25^{\circ} \mathrm{C}$, oleh karena itu keduanya bersifat sangat hidrofobik dan dengan cepat akan terjadi transfer massa dari fasa berair ke partikel tersuspensi, tanah atau sedimen (Fitzpatrick, 1982). Kisaran residu pestisida piretroid bawang merah disajikan pada Tabel II.

Keberadaan residu piretroid pada produk pertanian juga banyak dilaporkan oleh beberapa peneliti. Produk buahbuahan dan sayuran yang telah dipasarkan pun masih terdeteksi adanya residu pestisida piretroid seperti yang dilaporkan oleh Choy dan Seeneevassen (1998). Pada sampel tomat, kubis, selada dan sawi terdeteksi adanya residu $\alpha$-sipermetrin masing-masing sebesar 10-410; 0,13; 740,0 dan 420,0 ppb. Aplikasi insektisida $\lambda$-sihalotrin pada tanaman apel dapat meninggalkan residu baik pada daging buah maupun kulit apel, tetapi setelah 39 hari residu tidak terdeteksi pada daging buah sedangkan pada kulit masih dapat terdeteksi seperti yang dilaporkan oleh Bostanian dkk. (1993).

$\alpha$-Sipermetrin. $\quad \alpha$-Sipermetrin merupakan pestisida non-sistemik, berspektrum luas dalam mengendalikan hama, mempunyai aktivitas insektisidal yang dapat menyebabkan "knock down" pada serangga dengan cepat. Pestisida ini sangat efektif sebagai racun kontak dan racun lambung dalam mengendalikan hama target pada laju aplikasi yang relatif rendah. Pestisida ini beraksi dengan membloking chanel ion natrium yang terdapat pada membran syaraf. $\alpha$-Sipermetrin merupakan campuran rasemat antara (S)- $\alpha$-siano-3fenoksibenzil-(1R,3R)-3-(2,2-diklorovi nil)-2,2-dimetilsiklopropankarboksilat dan (R)-a-siano-3-fenoksibenzil(1S,3S)-3-(2,2-diklorovinil)-2,2dimetilsiklopropankarboksilat.

Residu pestisida $\alpha$-sipermetrin pada bawang merah cukup tinggi yaitu sebesar 98,8-245,6 ppb. Hal ini sesuai dengan penelitian yang dilakukan Choy dan Seeneevassen (1998) yang melaporkan bahwa sayuran pasca panen masih terdeteksi adanya residu pestisida seperti $\alpha$-sipermetrin. Pada sampel tomat, kubis, selada dan sawi terdeteksi adanya residu $\alpha$-sipermetrin masing-masing sebesar 10-410; 0,13; 740,0 dan 420,0 ppb.

Dalam tanaman, $\alpha$-sipermetrin mengalami metabolisme melalui pemutusan ikatan ester menghasilkan $\alpha$-siano-3-fenoksibenzilalkohol.Hidroksilasi juga terjadi, tetapi merupakan jalur minor. Metabolisme oleh tanaman lebih lanjut akan menghasilkan derivat monosakarida dan disakarida. Furuzawa dkk. (1981) melaporkan bahwa untuk isomer cis lebih stabil dibandingkan 
dengan isomer trans, dimana waktu paruh untuk isomer cis dan trans masing-masing adalah 7-8 dan 4-5 hari. Knisel (1993) melaporkan bahwa waktu paruh $\alpha$-sipermetrin pada daun adalah 5 hari.

$\alpha$-Sipermetrin bersifat hidrofobik, oleh karena itu $\alpha$-sipermetrin menunjukkan solubilitas dalam air yang rendah. $\alpha$-Sipermetrin adalah senyawa non polar dan dapat teradsorb pada permukaan tanah dan terikat dengan partikel tanah. Menurut Kaufmann dkk. (1981), hanya sedikit $\alpha$-sipermetrin yang bergerak sepanjang lapisan tanah, tetapi produk degradasinya bersifat lebih mobil bila dibandingkan dengan senyawa induknya.

Waktu paruh $\lambda$-sipermetrin di tanah adalah 2-8 minggu. $\lambda$-Sipermetrin mempunyai afinitas yang tinggi terhadap partikel tanah dan solubilitas di air yang rendah, hal ini menyebabkan senyawa tersebut terikat kuat di tanah sehingga potensi senyawa tersebut untuk mengkontaminasi air tanah adalah rendah (Knisel, 1993).

$\lambda$-Sihalotrin. $\lambda$-Sihalotrin merupakan campuran isomer $1: 1$ dari (S)- $\alpha$-siano-3-fenoksibenzil(Z)-(1R,3R) -3-(2-kloro-3,3,3,trifluoroprofenil)-2,2dimetil siklopropakarboksilat dan (R)- $\alpha$-siano-3-fenoksibenzil(Z)-(1S,3S) -3-(2-kloro-3,3,3-trifluoroprofenil)-2,2dimetilsiklopropankarboksilat.

$\lambda$-Sihalotrin merupakan padatan yang tak berwarna dan mempunyai bau yang tidak menyengat, bersifat volatil dan juga mempunyai solubilitas dalam air yang rendah.
$\lambda$-Sihalotrin bersifat stabil terhadap fotolisis, sehingga setelah aplikasi di lahan, senyawa tersebut tidak dapat langsung hilang melalui reaksi fotokimia. Selain itu, $\lambda$-sihalotrin mempunyai tekanan uap yang rendah yaitu sebesar 2.10-7 $\mathrm{Pa}$ dengan konstanta Henry sebesar $0,02 \mathrm{~Pa} \mathrm{~m} / \mathrm{mol}$ sehingga penguapan terjadi secara lambat. Aplikasi $\lambda$-sihalotrin pada tanaman mengakibatkan senyawa tersebut menempel pada permukaan daun dan dapat masuk melalui jaringan daun. Selain itu, dalam aplikasinya sering ditambahkan bahan perata, perekat dan pembasah sehingga pestisida mudah larut dalam air dan juga dapat bertahan lama di tanaman atau dengan kata lain, penghilangan akibat adanya leaching oleh air hujan, dapat berkurang.

Hasil analisis menunjukkan bahwa residu $\lambda$-sihalotrin yang terdapat dalam sampel bawang merah cukup tinggi dengan kisaran residu adalah 14,4-120,0 ppb. Aplikasi insektisida $\lambda$-sihalotrin pada tanaman apel dapat meninggalkan residu baik pada daging buah maupun kulit apel, tetapi setelah 39 hari residu tidak terdeteksi pada daging buah sedangkan pada kulit masih dapat terdeteksi seperti yang dilaporkan oleh Bostanian dkk. (1993).

Knisel (1993) melaporkan bahwa waktu paruh $\lambda$-sihalotrin pada permukaan daun adalah 5 hari. $\lambda$-Sihalotrin dapat dikatakan bersifat kurang persisten, tapi penggunaan insektisida tersebut secara berulang- ulang dan dalam jangka waktu yang lama perlu diwaspadai. Hal ini dikarenakan, penggunaan dalam jangka waktu yang lama dapat menyebabkan terjadinya 
resistensi bahkan resurjensi hama. Hill dan Inaba (1991) melaporkan bahwa disipasi $\lambda$-sihalotrin di tanah tergantung pada intensitas cahaya matahari dan kelembaban tanah. Waktu paruh $\lambda$-sihalotrin di tanah adalah 28-84 hari. $\lambda$-Sihalotrin mempunyai afinitas yang tinggi terhadap partikel tanah dan solubilitas di air yang rendah, hal ini menyebabkan senyawa tersebut terikat kuat di tanah sehingga potensi senyawa tersebut untuk mengkontaminasi air tanah adalah rendah

\section{Tingkat Residu Pestisida Pada Bawang Merah}

Hal yang menjadi perhatian terkait dengan residu pestisida adalah batas maksimum residu pestisida (BMR). BMR didefinisikan sebagai konsentrasi maksimum residu pestisida yang secara hukum diizinkan atau diketahui sebagai kadar yang dapat diterima dalam hasil pertanian, bahan pangan atau bahan pakan ternak. Tingkat residu pestisida pada bawang merah disajikan pada Tabel III.

BMR untuk berbagai jenis pestisida dan produk pertanian tertentu secara internasional ditetapkan oleh JMPR (Joint FAO/WHO Meeting on Pesticide Residues). Banyak data yang diperlukan untuk menetapkan BMRP termasuk hasil pemeriksaan tingkat residu pada percobaan lapangan terawasi berdasarkan pada GAP (Good Agriculture Practices), perkiraan pemasukan harian residu pestisida melalui makanan (predicted daily intake of pesticide residues), toksikologi dan ekotoksikologi pestisida, dan lain-lain.
Sampel yang melebihi BMR menunjukkan nilai residu yang besar, bila berada di rantai makanan sangat membahayakan kesehatan manusia karena senyawa $\alpha$-sipermetrin dan $\lambda$-sihalotrin bersifat toksik dan karsinogenik. USEPA mengklasifikasikan $\alpha$-sipermetrin ke dalam golongan $\mathrm{C}$ (potensi karsinogenik) dan $\lambda$-sihalotrin ke dalam golongan D. Meskipun masuk dalam golongan $\mathrm{D}$, tetapi $\alpha$-sihalotrin berpengaruh pada sistem reproduksi. Untuk sampel dengan kandungan residu di bawah BMR, konsumsi secara terusmenerus juga perlu diwaspadai, hal ini mengingat adanya sifat bioakumulasi pestisida.

\section{KESIMPULAN}

Berdasarkan hasil penelitian ditemukan kisaran kadar residu pestisida pada sampel bawang merah untuk $\alpha$-sipermetrin $(98,8-245,6 \mathrm{ppb})$ dan $\lambda$-sihalotrin (14,4-120,0 ppb). Terdapat kadar residu pestisida pada sampel bawang merah yang melebihi BMR, yang sangat berbahaya bagi kesehatan manusia karena bersifat toksik dan karsinogenik.

\section{DAFTAR PUSTAKA}

Ardiwinata, A.N., Jatmiko, S.Y., dan Harsanti, E.S., 1999, Monitoring Rresidu Insektisida di Jawa Barat, Risalah Seminar Hasil Penelitian Emisi Gas Rumah Kaca dan Peningkatan Produktivitas Padi di Lahan Sawah, Bogor, 91-105.

Bostanian, N.J., Andre, B., France, B., dan Gerard, M., 1993, Dissipation of Lambda-Cyhalothrin Residue 
Tabel III. Tingkat residu pestisida pada bawang merah

\begin{tabular}{|l|c|c|}
\hline \multicolumn{1}{|c|}{ Senyawa } & $\begin{array}{c}\text { Kadar residu pestisida pada bawang } \\
\text { merah (ppb) }\end{array}$ & BMR(ppb) \\
\hline $\begin{array}{l}\text { Piretroid: } \\
\alpha \text {-Sipermetrin }\end{array}$ & $\begin{array}{c}162,1^{*} \\
(98,8-245,6) \\
61,1\end{array}$ \\
$\lambda$-Sihalotrin & $(14,4-120,0)$ & $100^{2}$ \\
\hline
\end{tabular}

${ }^{*}$ Melebihi BMR

${ }^{1}$ BMR menurut Japan Food Chemical Research Foundation (JFCRF);

${ }^{2}$ BMR $\lambda$-Sihalotrin menurut Environmental Protection Agency ((EPA).

on Apple Foliage and Apple at Harvest, J. Agric. Food. Chem., 41, 292-295.

Chen, J.F., Chen, H.Y., Liu, R., He, J., Song, L., Bian, Q., Xu, L.C., Zhou, J.W., Xiao, H., Dai, G.D., Wang, X.R., 2005, Effect Fenvalerate on Steroidogenesis in Cultured Rat Granulose Cells, Biomed. Environ. Sci., 18, 108-116.

Choy, L.H.L.F., dan Seeneevassen, S., 1998, Monitoring Insecticide Residue In Vegetables and Fruits at The Market Level, Food Agricultural Research Council.

Fitzpatrick, R.D., 1982, A Gas-Liquid Chromathographic Method for the Determination of Cypermethrin (PP383) in Crops, Soil and Water. ICI Americas, Agricultural Chemicals Division, Research and Development Department.

Furuzawa K.N., Mikami, H., Yamada dan Miyamoto, J., 1981, Metabolism of The Pyrethroid Insecticide Cypermethrin in
Cabbage, J. Pestic. Sci, 11, 253-260.

Harsanti, E.S., Jatmiko, S.Y. dan Ardiwinata, A.N., 1999, Residu Insektisida pada Ekosistem Lahan Irigasi di Jawa Timur, Risalah Seminar Hasil Penelitian Emisi Gas Rumah Kaca dan Peningkatan Produktivitas Padi di Lahan Sawah, 119-128.

Hill, B.D., dan Inaba, D.J., 1991, Dissipation of Lambda-Cyhalothrin on Fallow Vs Cropped Soil, J. Agric. Food. Chem., 39, 2282-2284.

Ishii, Y., 2003, Development of Efficient Methods for Pesticide Residue Analysis of Agro-Environmental Samples, J. Pestic. Sci., 28, 217-218. 218.

Jatmiko, S.Y., Harsanti, E.S dan Ardiwinata, A.N., 1999, Pencemaran Pestisida pada Agroekosistem Lahan Sawah Irigasi dan Tadah Hujan di Jawa Tengah, Risalah Seminar Hasil Penelitian Emisi Gas Rumah Kaca dan Peningkatan 
Produktivitas Padi di Lahan Sawah, 106-118.

Kaufman, D.D., Russell, B.A., Helling, C.S. dan Kayser, A.J., 1981, Movement of Cypermethrin, Decamethrin, Permethrin, and Their Degradation Products in Soil, J. Agric. Food. Chem., American Chemical Society, Washington D.C., 239-245.

Kim, S.S., Lee, R.D., Lim, K.J., Kwack, S.J., Rhee, G.S., Seok, J.H., Lee, G.S., An, B.S., Jeung, E.B., Park, K.L., 2005, Potential Estrogenic and Antiandrogenic Effects of Permethrin in Rats, Journal of Reproduction and Development, 51, 201-210.

Knisel, W.G., 1993, Groundwater Loading Effects of Agricultural Management Systems, United States Department on Agriculture, Agricultural Research Servise, Tifton, Georgia.
Laksanawati, H., Dibyantoro, H., Gunawan, O.S., Suriaatmadja, R.E., Sulatri I. dan Suparman, M., 1994, Deteksi Residu Pestisida pada Wortel dan Seledri di Beberapa Sentra Produksi di Jawa Barat dan Jawa Tengah, Buletin Penelitian Holtikultura, vol 27 (1), 89-97.

Ohsawa, K., Hartati, S., Nugrahati, S., Sastrohamidjoyo, H., Untung, K., Arya, N., Sumiarta, K. dan Kuwatsuka, S., 1985, Residue Analysis of Organochlorine and Organophosphorus Pesticides in Soil, Water, and Vegetables from Central Java and Bali, Ecol./impact of IPM in Indonesia, 59-70.

Willard, H.H., Merritt, Jr., Dean, J.A., Settle, Jr., F.A., 1988, Instrumental Method of Analysis, edisi 7, Wadsworth Publishing Co., California. 